\title{
Kompetensi Petani Unggul dalam Membentuk Capacity Building Pertanian Sayuran Dataran Tinggi di Sumatera
}

\author{
Superior Farmer Competence in Forming the Capacity Building of Highland Vegetable \\ Farming in Sumatera
}

\author{
Raysah Yunita Rahma"1, Muhammad Syamsun ${ }^{\sharp 2}$, dan Anggraini Sukmawati ${ }^{\ddagger 2}$ \\ ${ }^{1}$ Program Magister Manajemen, Fakultas Ekonomi dan Manajemen Institut Pertanian Bogor \\ ${ }^{2}$ Departemen Manajemen, Fakultas Ekonomi dan Manajemen, Institut Pertanian Bogor \\ "Jl. Kamper, Kampus IPB Darmaga, Bogor 16680
}

\begin{abstract}
ABSTRAK
Potensi pertanian di Indonesia masih menjadi keunggulan, dikarenakan Indonesia merupakan negara agraris. Peran sektor pertanian dalam perekonomian nasional secara empiris terbukti cukup nyata, baik dalam perekonomian cukup normal maupun pada saat perekonomian menghadapi krisis. Hal ini dilihat dari dua indikator penting, yaitu kontribusi pada sektor Produk Domestik Bruto (PDB) dan penyerapan tenaga kerja yang selalu mendominasi dalam bidang pertanian. Hal ini disebabkan kurangnya kompetensi petani untuk dapat berkembang pada sektor pertanian, maka itu dibutuhkan kompetensi petani dalam membentuk capacity building pertanian, sehingga petani dapat berperan dalam masyarakat dan dapat bersaing pada era globalisasi saat ini. Penelitian ini bertujuan untuk: (1) menganalisis bagaimana kompetensi yang dimiliki petani di Sumatera, (2) memperoleh gambaran model kompetensi unggul petani di Sumatera guna membentuk capacity building petani sayuran dataran tinggi dan (3) memberikan solusi apakah yang harus dilakukan untuk meningkatkan kompetensi petani di Sumatera. Untuk menganalisiskompetensi unggul petani dan pembuatan model kompetensi unggul dalam membentuk capacity building pertanian sayuran dataran tinggi di Sumatera, digunakan ISM (Intrepretive Structural Modelling), AHP (Analysis Hirarki Process) dan IPA (Importance Performance Analysis).
\end{abstract}

Kata Kunci: kompetensi, petani unggul, capacity building, pertanian sayuran, dataran tinggi

\begin{abstract}
The agricultural potential in Indonesia still becomes the excellence because Indonesia is the agrarian country. The role of agricultural sector in the national economy is empirically proven to be real enough both in quite normal economy and when the economy facing the crisis. This is seen from two important indicators i.e. the contribution to the sector of Gross Domestic Product (GDP), and the labor absorption that always dominates in the agricultural field.This is caused by the lack of competence of farmer to be able to develop in the agricultural sector. With this is needed the farmer competence in forming the farming capacity building so the farmer can play the role in the community and can compete in the current globalization era. Based on the above problem, the research aims to: (1) analyze how the competence is owned by the farmer in Sumatera, (2) obtain the picture of farmer superior competence model in Sumatera to form the capacity building of highland vegetable farmer, and (3) give any solution which should be done in order to be able to increase the farmer competence in Sumatera. In this research, for analyzing the farmer superior competence and the making of superior competence model in forming the capacity building of highland vegetable farming in Karo District, it is used the ISM, AHP, and IPA.
\end{abstract}

Keywords: competence, superior farmer, capacity building, highland, vegetable farming

\footnotetext{
*) Korespondensi:

Jl. Kamper, Kampus IPB Darmaga, Bogor 16680; e-mail: raysahyunitarahma@gmail.com
} 


\section{PENDAHULUAN}

Potensi pertanian di Indonesia masih menjadi keunggulan, dikarenakan Indonesia merupakan negara agraris. Potensi pertanian dan kemampuan petani di masing-masing daerah, yang pada hakekatnya didasarkan pada kebijakan yang mendorong peningkatan kemampuan wilayah, dalam menentukan sektor-sektor kunci (key sectors) dan mempunyai keterkaitan kuat dengan aspek pembangunan lainnya di Indonesia, menjadikan aspek pertanian tetap menjadi yang utama terhadap pendapatan nasional Indonesia.

Peran sektor pertanian dalam perekonomian nasional secara empiris terbukti cukup nyata baik dalam perekonomian yang cukup normal maupun pada saat perekonomian menghadapi krisis. Hal ini dilihat dari dua indikator penting, yaitu kontribusi pada sektor Produk Domestik Bruto (PDB) dan penyerapan tenaga kerja. Dapat dilihat pada tahun 2012,kontribusisektor pertanian terhadap pendapatan nasional Indonesia berdasarkan besarnya peningkatan nilai PDB, yaitu atas dasar harga berlaku sebesar Rp1091,4 triliun meningkat menjadi Rp1190,4 Triliun. Pada tahun 2012 mengalami pertumbuhan 3,97\% (BPS, 2012).

Dilihat dari penyerapan tenaga kerja sektoral, sektor pertanian mendominasi penyerapan tenaga kerja di Indonesia, yaitupada tahun 2012 sektor pertanian menyerap tenaga kerja 41,20 juta jiwa. Nilai ini jauh lebih besar daripada penyerapan tenaga kerja oleh sektor perdagangan yang berada pada urutan kedua, yaitu 24,02 juta jiwa dan urutan ketiga sektor industri sebanyak 14,21 juta jiwa (Sumarni, 2008).

Dalam menghadapi persaingan globalisasi saat ini, faktor sumber daya manusia (SDM) merupakan faktor dominan yang menentukan daya saing. Faktor lain yang memengaruhi antara lain pasar, finansial, teknologi, pemasok, infrastrukturdan lingkungan, serta kebijakan kondusif. Untuk ekonomi berbasiskan kepada pertanian, faktor SDM merupakan faktor yang cukup dominan. Pencarian SDM di bidang pertanian merupakan hal yang tidak terlalu sulit, tetapi pencarian SDM yang kompeten di bidang pertanian merupakan hal yang sangat sulit secara nyata (Hasibuan, 1997).

Pertanian memegang peran strategik dalam perekonomian Nasional dan Daerah, bahkan dalam era Reformasi ini diharapkan berperan di garis depan dalam mengatasi krisis Ekonomi. Sektor pertanian di wilayah Sumatera mengalami kenaikan, yaitu 21,19\% menjadi 24,05\%. Sumbangan terbesar datang dari Kabupaten Agam, Sumatera Barat dengan sumbangan nilai tambah dari sektor pertanian pada tahun 2013, terdapat Produk Domestik Regional Bruto (PDRB) mencapai $39,72 \%$, dengan laju pertumbuhan $7,01 \%$ (BPS Sumatera Barat, 2013).

Selain itu Kabupaten Karo, Sumatera Utara, yang terbentang pada ketinggian 600-1.400 m di atas permukaan laut (dpl), sangat potensial sebagai daerah penghasil komoditas hortikultura, terutama sayuran. Tidak mengherankan jika kabupaten berpenduduk lebih dari 42 ribu jiwa ini masih mengandalkan sektor pertanian sebagai kegiatan ekonomi, yaitu 75\% lapangan usaha masyarakat bekerja di sektor pertanian.

Sebagai salah satu daerah pusat penghasil sayuran, Kabupaten Karo memiliki kontribusi cukup besar dalam kegiatan ekspor sayuran Sumatera Utara yang terus mengalami kenaikan pada akhir tahun 2012. Namun, temuan di lapangan menunjukkan bahwa pasar sayuran petani Karo dikalahkan oleh sayuran dari daerah lain diluar Sumatera bahkan impor dari luar negeri, maka sayuran dijual dengan harga lebih murah di pasar-pasar di wilayah Kabupaten Karo agar tetap laku, tetapi mengakibatkan kerugian pada para petani. Tujuan penelitian ini menganalisis kompetensi yang dimiliki petani di Sumatera dan memperoleh gambaran model kompetensi unggul petani di Sumatera guna membentuk capacity building petani sayuran dataran tinggi, untuk memiliki nilai tambah tersendiri bagi dirinya dan orang lain.

\section{METODOLOGI}

Penelitian ini terdiri dari beberapa tahap, yaitu pra penelitian, pengumpulan data, analisis data dan penutup. Pada tahap pra penelitian terdiri dari identifikasi minat penelitian, pemilihan topik penelitian dan studi pustaka, penentuan topik penelitian, perumusan masalah dan rancangan pengumpulan data. Pengumpulan data terdiri dari studi pendahuluan, studi pustaka dan opini pakar. Kemudian dilanjutkan dengan pengumpulan data lapangan. Penelitian ini menggunakan ISM (Interpretive Structural Modelling) dengan menganalisis enam unsur yang terdiri dari kebutuhan, kendala, perubahan, tujuan, aktivitas dan pelaku. Menurut Raeesi et al (2013), ISM menganalisis elemen-elemen sistem dan memecahkannya dalam bentuk grafik dari 
hubungan langsung antar elemen dan tingkat hirarki. Menurut Indrawanto (2009), Interpretive Structural Modeling (ISM), menyediakan kerangka kerja yang terarah untuk masalah yang kompleks, dan memberikan pengambil keputusan gambaran realistis dan jelas tentang sistem dan variabel yang terlibat nya. Elemen-elemen yang dianalisis pada kompetensi petani sayuran dataran tinggi ini adalah kebutuhan petani, struktur kelembagaan, kendala keber-lanjutan model kompetensi, dan pengurangan risiko dalam model kompetensi. Kemudian analisis menggunakan AHP (Analytical Hierarchy Process) agar didapatkan suatu model kompetensi unggul petani di Sumatera untuk membentuk capacity building petani sayuran dataran tinggi, serta menggunakan IPA (Importance Performance Analysis) untuk memberikan solusi apa yang harus dilakukan, agar dapat meningkatkan kompetensi petani di Kabupaten Karo.

Teknik pengambilan contoh dengan non probability sampling, yaitu purposive sampling. Contoh diambil didasarkan beberapa kriteria tertentu yang telah ditetapkan. Dalam hal ini, pakar berperan penting dalam memberikan penilaian terhadap permasalahan yang ada. Selain pakar, stakeholder yang terlibat dalam pertanian juga dibutuhkan untuk memberikan informasi terkait dengan kompetensi petani.

\section{HASIL DAN PEMBAHASAN}

\section{Hasil Pengolahan AHP}

Berdasarkan hasil kuesioner pakar diperoleh perbandingan berpasangan antara fokus utama sebagai kontrol dan kebutuhan, akan dilihat mana yang memiliki pengaruh paling besar. Analisis keputusan ini merupakan hasil gabungan analisis keputusan dari dua kabupaten di Sumatera, yaitu Kabupaten Agam, Sumatera Barat dan Kabupaten Karo, Sumatera Utara. Hasil analisis ini menunujukkan bobot dari masingmasing peubah pada setiap hiraki. Pada hirarki kebutuhan yang paling berpengaruh adalah pemenuhan kebutuhan sarana pertanian. Peubah ini memiliki bobot terbesar, yaitu 0,424. Pada hirarki kedua, merupakan kendala yang diperoleh dari perbandingan antara kebutuhan sebagai kontrol utama dan kendala, didapatkan hasil penerapan teknologi yang belum optimal 0,391. Hirarki ketiga dengan bobot merupakan hasil perbandingan antara kendala sebagai kontrol dan perubahan, memberikan hasil terbesar, yaitu menghasilkan sayuran bermutu tinggi dengan bobot 0,4 . Hirarki keempat merupakan perbandingan antara perubahan sebagai kontrol utama dan tujuan, yaitu dapat meningkatkan keterampilan petani dengan bobot 0,528 . Hirarki kelima merupakan perbandingan antara tujuan sebagai kontrol utama dan aktivitas, dengan kontribusi PEMDA dalam meningkatkan sarana dan prasarana dengan bobot 0,62. Pada hirarki terakhir yang merupakan antara aktivitas sebagai kontrol dan pelaku, memberikan PEMDA sebagai pengaruh terbesar pada hirarki ketujuh dengan bobot 0,573 .

\section{Model Kompetensi Unggul Petani}

Setelah dilakukan penilaian dengan AHP maka disusunlah model kompetensi unggul petani dengan mengkombinasikan sebagai prioritas pada setiap hirarki. Berdasarkan hasil AHP, pada hirarki pertama hingga hirarki ketujuh didapatkan hasil dengan terpenuhinya pemenuhan kebutuhan sarana pertanian di Sumatera juga dengan adanya aktivitas Pemerintah Daerah (PEMDA) dalam meningkatkan sarana dan prasarana pertanian, kendala utama yang dihadapi oleh petani di Sumatera seperti penerapan teknologi yang belum optimal akan terminimalisir, sehingga terjadi perubahan yang dimungkinkan, yaitu petani akan mudah dalam menghasilkan sayuran mutu tinggi, sehingga tujuan untuk meningkatkan keterampilan petani akan tercapai. Struktur hirarki dapat dilihat pada Gambar 1.

\section{Analisis ISM pada Kabupaten Agam, Sumatera Barat}

\section{Kebutuhan}

Pada unsur kebutuhan, variabel pemenuhan kebutuhan sarana (benih, pupuk, pestisida, dll) (1), Pelatihan dan pendampingan oleh Pemerintah dalam hal pertanian (3), Pengetahuan di lapang dalam menghasilkan produk pertanian yang unggul (4), Networking dalam membangun kerja sama pertanian (6), Kesadaran untuk berpendidikan formal (7) dan sikap pantang menyerah dalam berinovasi (8), merupakan peubah yang berada pada top level dan paling memengaruhi unsur kebutuhan. Peubah yang berada pada top level ini memiliki driving power yang rendah dan ketergantungan antar peubah yang artinya akan memiliki ketergantungan dengan peubah yang berada di bottom level.

Peubah yang berada pada bottom level ini memiliki sifat driver atau pengaruh yang kuat 


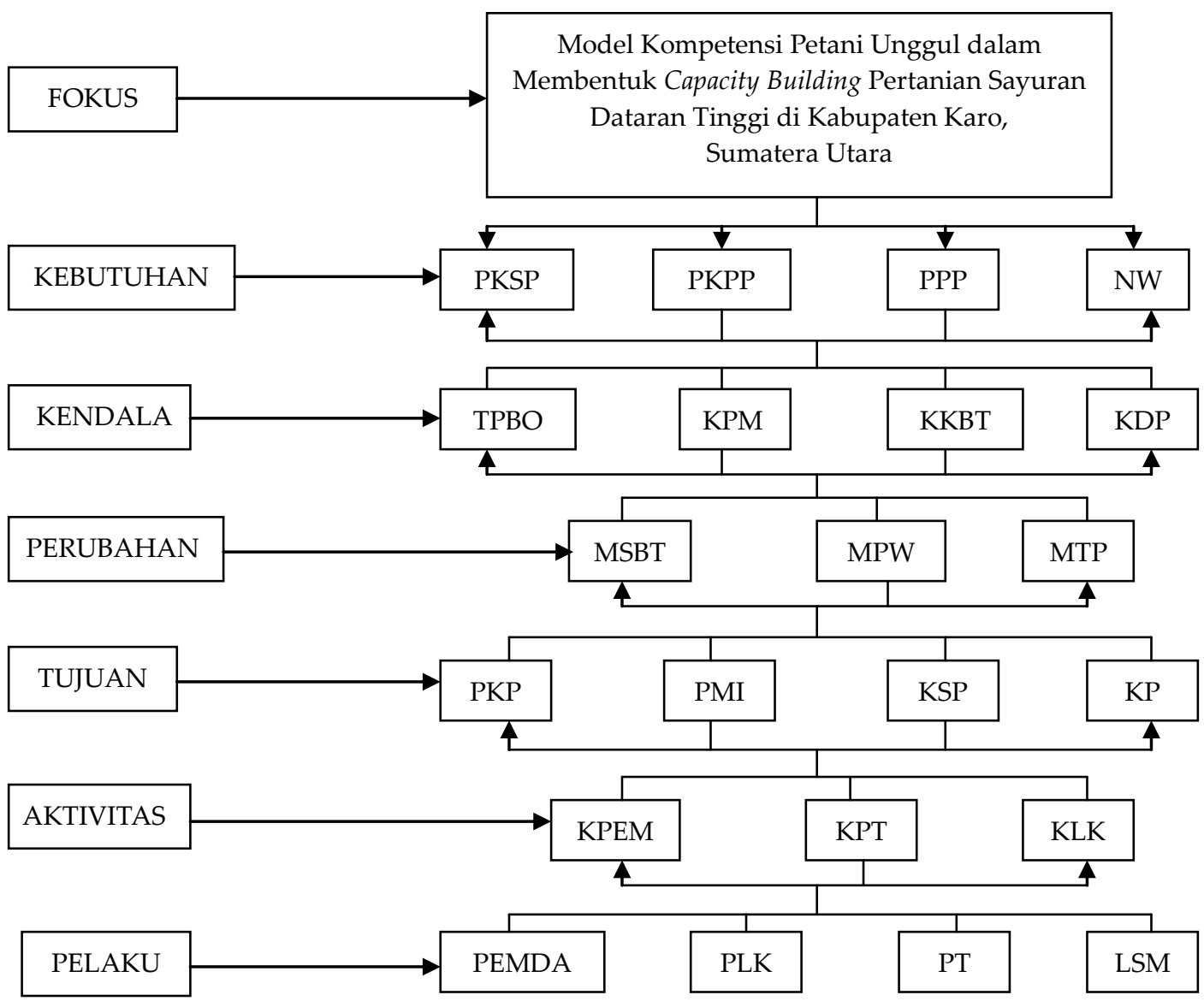

Gambar 1. Struktur hirarki model kompetensi unggul petani dalam membetuk capacity building pertanian sayuran dataran tinggi di Sumatera (Saaty, 1991)

terhadap peubah yang berada di level atasnya, sehingga dapat menciptakan kompetensi petani unggul. Pemenuhan kebutuhan prasarana (alatalat pertanian, teknologi pertanian, dll) yang memadai (2) dan keterampilan dalam bertani dan memanfaatkan sarana produksi pertanian (5) secara tidak langsung akan membantu tercapainya unsur kebutuhan. Model dasar interaksi antar sub-unsur kebutuhan pada ISM dapat dilihat pada Gambar 2.

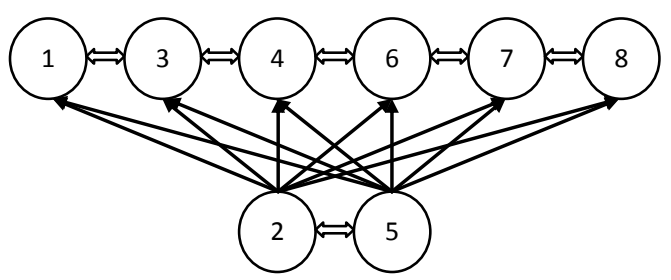

Gambar 2. Model dasar interaksi antar sub-unsur kebutuhan pada ISM

\section{Kendala}

Pada unsur kendala, penerapan teknologi pertanian masih belum optimal pada petaninya (1) dan kurangnya komitmen dan dukungan (3) adalah peubah paling memengaruhi pada unsur kendala. Peubah yang berada pada top level ini memiliki driving power rendah dan ketergantungan antar peubah, yang artinya akan memiliki ketergantungan dengan peubah yang berada di middle level dan bottom level.

Peubah-peubah yang berada pada middle level ini akan memiliki pengaruh cukup besar terhadap peubah yang berhubungan dengan peubah terhubung. Mutu sarana produksi pertanian yang kurang baik (7) pada middle level dicapai dengan melakukan perbaikan pada bottom level terlebih dahulu. Peubah yang berada pada bottom level ini memiliki sifat driver atau pengaruh kuat terhadap peubah yang berada di level atasnya, sehingga kendala permodalan(2), kurangnya pelatihan dan pengembangan keterampilan untuk petani (4), kurangnya kesadaran petani untuk berpendidikan formal (5) dan kurangnya dukungan pemerintah, serta (6) dapat memperkecil timbulnya kendala. Model dasar interaksi antar sub-unsur kendala pada ISM dapat dilihat pada Gambar 3. 


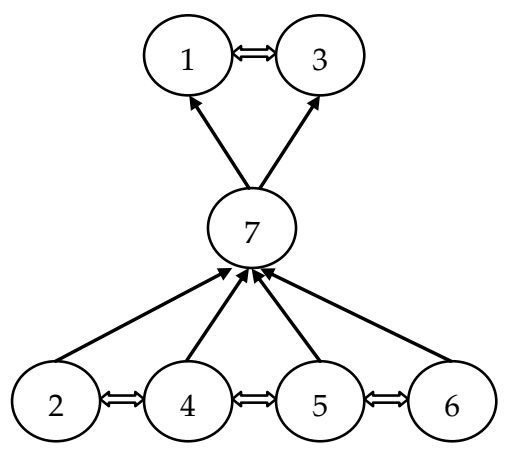

Gambar 3. Model dasar interaksi antar sub-unsur kendala pada ISM

\section{Perubahan}

Pada unsur perubahan, peubahpetani mampu menjadi petani wirausaha (2) sebagai peubah yang berada pada top leveldan paling memengaruhi unsur perubahan. Peubah yang berada pada top level ini memiliki driving power yang rendah dan ketergantungan antar peubah yang artinya akan memiliki ketergantungan dengan peubah yang berada di middle level dan bottom level.

Peubah-peubah yang berada pada middle levelakan memiliki pengaruh cukup besar terhadap peubah yang berhubungan dengan peubah terhubung. Petani dapat menghasilkan sayuran yang memiliki mutu tinggi (1), dimana petani dapat mengaplikasikan teknologi pertanian yang tepat guna (4) dan Petani dapat menerapkan pengetahuan-pengetahuan yang diperlukan dalam bertani (5),pada middle level ini dengan melakukan perbaikan pada bottom level terlebih dahulu. Peubah yang berada pada bottom level ini memiliki sifat driver atau pengaruh kuat terhadap peubah yang berada di level atasnya, sehingga dapat meningkatkan kompetensi unggul petani dalam proses menuju perubahan. Petani menyadari pentingnya pendidikan formal untuk meningkatkan kapasitas (3) secara tidak langsung akan membantu unsur perubahan dalam melakukan prosesnya. Model dasar interaksi antar subunsur perubahan pada ISM dapat dilihat pada Gambar 4.

\section{Tujuan}

Pada unsur tujuan, petani mampu memiliki lahan sendiri (4), merupakan peubah yang berada pada top level dan paling memengaruhi unsur tujuan. Peubah yang berada pada top level ini memiliki driving power yang rendah dan ketergantungan antar peubah yang artinya akan memiliki ketergantungan dengan peubah yang berada dibottom level.
Peubah yang berada pada bottom level ini memiliki sifat driver atau pengaruh kuat terhadap peubah yang berada di level atasnya, sehingga dapat menciptakan kompetensi petani unggul. Peningkatan mutu petani (1), peningkatan pengetahuan petani dalam hal membuat inovasi (2), terciptanya kerjasama yang baik dengan Pemerintah (3) dan kemandirian petani, sehingga mampu menciptakan nilai tambah tersendiri (5) merupakan peubah yang berada pada bottom level dan secara tidak langsung akan membantu tercapainya unsur tujuan. Model dasar interaksi antar sub-unsur tujuan pada ISM dapat dilihat pada Gambar 5.

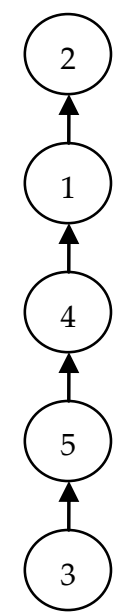

Gambar 4. Model dasar interaksi antar sub-unsur perubahan pada ISM

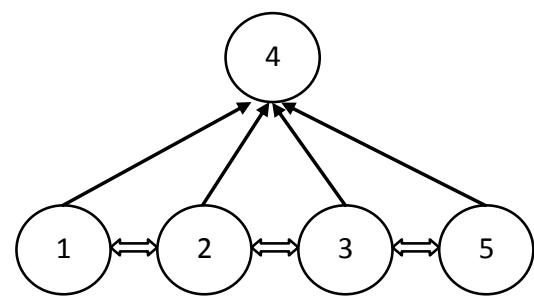

Gambar 5. Model dasar interaksi antar sub-unsur tujuan pada ISM

\section{Aktivitas}

Pada unsur aktivitas, peubahLSM dapat berkontribusi dalam meningkatkan keterampilan (mutu) petani (3), merupakan peubah yang berada pada top level dan paling memengaruhi unsur aktivitas. Peubah yang berada pada top level ini memiliki driving power rendah dan ketergantungan antar peubah,yang artinya akan memiliki ketergantungan dengan peubah yang berada di middle level dan bottom level.

Peubah-peubah yang berada pada middle level akan memiliki pengaruh cukup besar 
terhadap peubah yang berhubungan dengan peubah terhubung. Perguruan Tinggi dapat berkontribusi dalam meningkatkan keterampilan (mutu) petani (2), PEMDA dapat berkontribusi dalam meningkatkan keterampilan (mutu) petani (1), PEMDA dapat berbagi fasilitas atau sarana dan prasarana yang memadai (5), Lembaga keuangan dapat berkontribusi dalam meningkatkan keterampilan (mutu)petani(4) dan Lembaga keuangan dapat berbagi fasilitas atau sarana dan prasarana yang memadai (8) pada middle level ini hanya dapat dicapai, bila melakukan perbaikan pada bottom level terlebih dahulu. Peubah yang berada pada bottom level ini memiliki sifat driver atau pengaruh kuat terhadap peubah yang berada di level atasnya, sehingga dapat meningkatkan kompetensi unggul petani dalam menjalankan aktivitas yang mendukung kemandirian petani. Perguruan Tinggi dapat berbagi fasilitas atau sarana dan prasarana yang memadai (6) dan LSM dapat berbagi fasilitas atau sarana dan prasarana yang memadai (7),secara tidak langsung akan membantu kinerja unsur aktivitas secara keseluruhan dalam membangun kemandirian petani. Model dasar interaksi antar sub-unsur aktivitas pada ISM dapat dilihat pada Gambar 6.

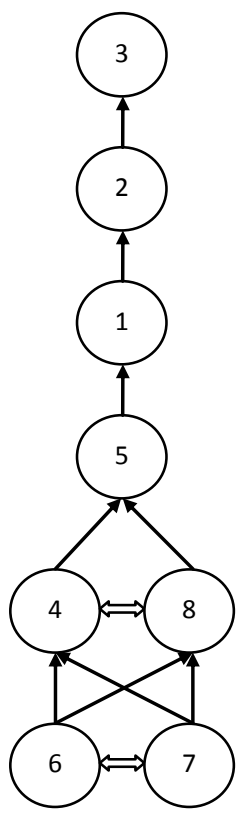

Gambar 6. Model dasar interaksi antar sub-unsur aktivitas pada ISM

\section{Pelaku}

Pada unsur pelaku, peubah Perguruan Tinggi (3) dan LPK (Lembaga Pendidikan dan Keterampilan) (7), merupakan peubah yang berada pada top level dan paling memengaruhi unsur pelaku. Peubah yang berada pada top level ini memiliki driving power yang rendah dan ketergantungan antar peubah yang artinya akan memiliki ketergantungan dengan peubah yang berada di middle level dan bottom level.

Peubah-peubah yang berada pada middle level ini akan memiliki pengaruh cukup besar terhadap peubah yang berhubungan dengan peubah terhubung. Perbankan dan lembaga keuangan lain (2), lembaga penjamin keuangan (4), penyuluh keuangan (5) dan LSM (6) pada level ini dapat memaksimalkan kontribusinya, bila melakukan pembenahan kontribusi pada bottom level terlebih dahulu. Peubah yang berada pada bottom level ini memiliki sifat driver atau pengaruh kuat terhadap peubah yang berada di level atas-nya, sehingga dapat meningkatkan kompetensi unggul petani. Memperbaiki kontribusi PEMDA (1) dalam meningkatkan mutu petani secara tidak langsung akan memperbaiki kinerja konribusi dari unsur pelaku. Model dasar interaksi antar sub-unsur pelaku pada ISM dapat dilihat pada Gambar 7.

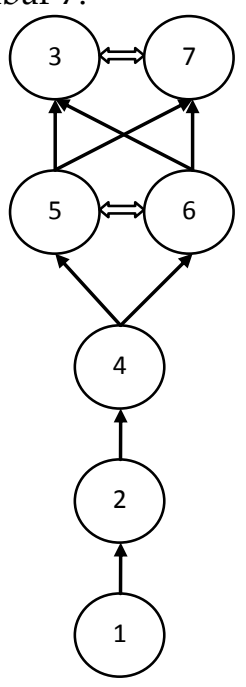

Gambar 7. Model dasar interaksi antar sub-unsur pelaku pada ISM

\section{Analisis ISM pada Kabupaten Karo, Sumatera Utara}

\section{Kebutuhan}

Pada unsur kebutuhan, peubah pemenuhan kebutuhan sarana (benih, pupuk, pestisida, dll) (1), Pemenuhan kebutuhan prasarana (alat-alat pertanian, teknologi pertanian, dll yang memadai) (2), Networking dalam membangun kerjasama pertanian (6), dan sikap pantang menyerah dalam berinovasi (8), merupakan peubah yang berada pada top leveldan paling memengaruhi unsur kebutuhan. Peubah yang berada pada top level ini 
memiliki driving power yang rendah dan ketergantungan antar peubah, yang artinya akan memiliki ketergantungan dengan peubah yang berada di middle level dan bottom level.

Peubah-peubah yang berada pada middle level ini akan memiliki pengaruh cukup besar terhadap peubah yang berhubungan dengan peubah terhubung. Keterampilan dalam bertani dan memanfaatkan sarana produksi (5), kesadaran dalam berpendidikan formal (8), pengetahuan di lapang dalam menghasilkan produk pertanian unggul, yaitu dicapai dengan melakukan perbaikan pada bottom level terlebih dahulu. Peubah yang berada pada bottom level ini memiliki sifat driver atau pengaruh yang kuat terhadap peubah yang berada di level atasnya sehingga dapat menciptakan model kompetensi unggul petani.

Pelatihan dan pendampingan oleh Pemerintah dalam hal pertanian (3), secara tidak langsung akan memperbaiki kinerja dari unsur kebutuhan. Model dasar interaksi antar sub-unsur kebutuhan pada ISM dapat dilihat pada Gambar 8.

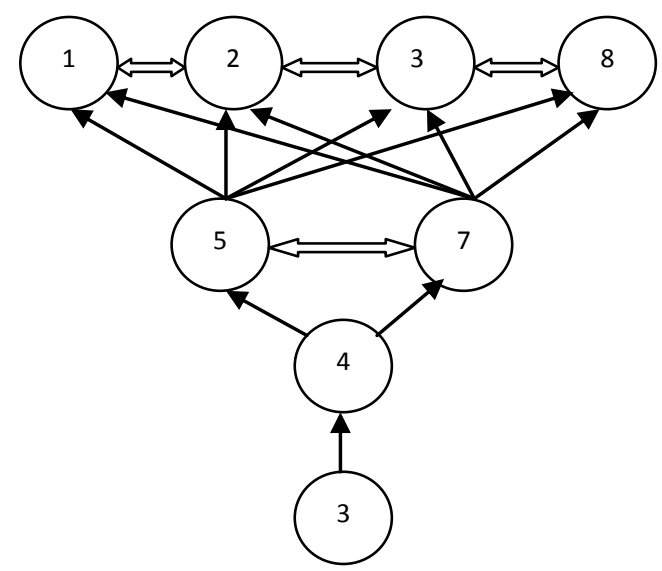

Gambar 8. Model dasar interaksi antar sub-unsur kebutuhan pada ISM

\section{Kendala}

Pada unsur kendala, penerapan teknologi pertanian yang masih belum optimal pada petaninya (1) dan kurangnya komitmen dan dukungan (3) adalah peubah yang paling mempengaruhi unsur kendala. Peubah yang berada pada top level ini memiliki driving power yang rendah dan ketergantungan antar unsur yang artinya akan memiliki ketergantungan dengan unsur yang berada di middle level dan bottom level.

Peubah-peubah yang berada pada middle level ini akan memiliki pengaruh cukup besar terhadap peubah yang berhubungan dengan peubah terhubung. Mutu sarana produksi pertanian yang kurang baik (7) pada middle level hanya dapat dicapai, bila melakukan perbaikan pada bottom level terlebih dahulu. Peubah yang berada pada bottom level ini memiliki sifat driver atau pengaruh kuat terhadap peubah yang berada di level atasnya, sehingga kendala permodalan (2), kurangnya pelatihan dan pengembangan pertanian keterampilan untuk petani (4), kurangnya kesadaran petani untuk berpendidikan formal (5) dan kurangnya dukungan pemerintah (6), dapat memperkecil timbulnya kendala. Model dasar interaksi antar sub-unsur kendala pada ISM dapat dilihat pada Gambar 9.

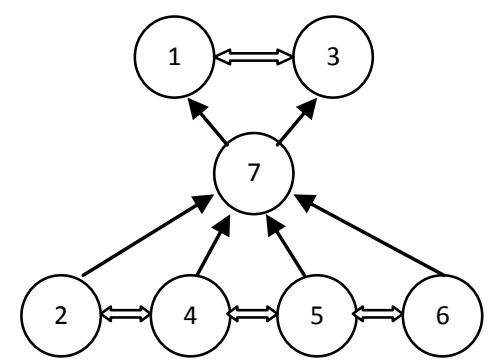

Gambar 9. Model dasar interaksi antar sub-unsur kendala pada ISM

\section{Perubahan}

Pada unsur perubahan, peubah petani mampu menjadi petani wirausaha (2) merupakan peubah yang berada pada top level dan paling memengaruhi unsur perubahan. Peubah yang berada pada top level ini memiliki driving power rendah dan ketergantungan antar peubah yang artinya akan memiliki ketergan-tungan dengan peubah yang berada di middle level dan bottom level.

Peubah-peubah yang berada pada middle level akan memiliki pengaruh cukup besar terhadap peubah yang berhubungan dengan peubah terhubung. Petani dapat menghasilkan sayuran yang memiliki mutu tinggi (1), petani dapat mengaplikasikan teknologi pertanian yang tepat guna (4) dan petani menyadari pentingnya pendidikan formal untuk meningkatkan kapasitas (3), pada middle level ini hanya dapat dicapai, bila melakukan perbaikan pada bottom level terlebih dahulu. Peubah yang berada pada bottom level ini memiliki sifat driver atau pengaruh yang kuat terhadap peubah yang berada di level atasnya sehingga dapat meningkatkan kompetensi unggul petani dalam proses menuju perubahan. Petani dapat menerapkan pengetahuan-pengetahuan yang diperlukan dalam bertani (5) secara tidak langsung akan membantu unsur perubahan dalam melakukan prosesnya. Model dasar 
interaksi antar sub-unsur perubahan pada ISM dapat dilihat pada Gambar 10.

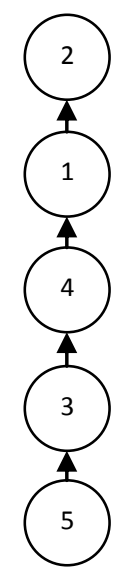

Gambar 10. Model dasar interaksi antar sub-unsur perubahan pada ISM

\section{Tujuan}

Pada unsur tujuan, peubah peningkatan mutupetani (1), peningkatan pengetahuan petani dalam hal membuat inovasi (2), petani mampu memiliki lahan sendiri (4) dan kemandirian petani, sehingga mampu menciptakan nilai tambah tersendiri (5) merupakan peubah yang berada pada top level dan paling memengaruhi peubah tujuan. Peubah yang berada pada top level ini memiliki driving power rendah dan ketergantungan antar peubah, yang artinya akan memiliki ketergantungan dengan peubah yang berada di bottom level.

Peubah yang berada pada bottom level ini memiliki sifat driver atau pengaruh kuat terhadap peubah yang berada di level atasnya, sehingga dapat menciptakan kompetensi petani unggul. Terciptanya kerjasama yang baik dengan Pemerintah (3) secara tidak langsung akan membantu tercapainya unsur tujuan. Model dasar interaksi antar sub-unsur tujuan pada ISM dapat dilihat pada Gambar 11.

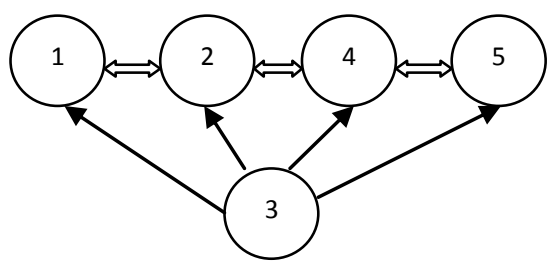

Gambar 11. Model dasar interaksi antar sub-unsur tujuan pada ISM

\section{Aktivitas}

Pada unsur aktivitas, peubah LSM dapat berkontribusi dalam meningkatkan keterampilan (mutu) petani (3), merupakan peubah yang berada pada top level dan paling memengaruhi unsur aktivitas. Peubah yang berada pada top level ini memiliki driving power rendah dan ketergantungan antar peubah, yang artinya akan memiliki ketergantungan dengan peubah yang berada di middle level dan bottom level.

Peubah-peubah yang berada pada middle level akan memiliki pengaruh cukup besar terhadap peubah yang berhubungan dengan peubah terhubung. LSM dapat berbagi fasilitas atau sarana dan prasarana yang memadai (7), PEMDA dapat berkontribusi dalam meningkatkan keterampilan (mutu) petani (1), Perguruan Tinggi dapat berkontribusi dalam meningkatkan keterampilan (mutu) petani (2), PEMDA dapat berbagi fasilitas atau sarana dan prasarana yang memadai (5) dan Perguruan Tinggi dapat berbagi fasilitas atau sarana dan prasarana yang memadai (6) pada middle level ini hanya dapat dicapai, bila melakukan perbaikan pada bottom levelterlebih dahulu. Peubah yang berada pada bottom level ini memiliki sifat driver atau pengaruh yang kuat terhadap peubah yang berada di level atasnya, sehingga dapat meningkatkan kompetensi unggul petani dalam menjalankan aktivitas yang mendukung kemandirian petani. Lembaga keuangan dapat berkontribusi dalam meningkatkan keterampilan (mutu) petani (4) dan Lembaga keuangan dapat berbagi fasilitas atau sarana dan prasarana yang memadai (8) secara tidak langsung akan membantu kinerja unsur aktivitas secara keseluruhan dalam membangun kemandirian petani. Model dasar interaksi antar sub-unsur aktivitas pada ISM dapat dilihat pada Gambar 12.

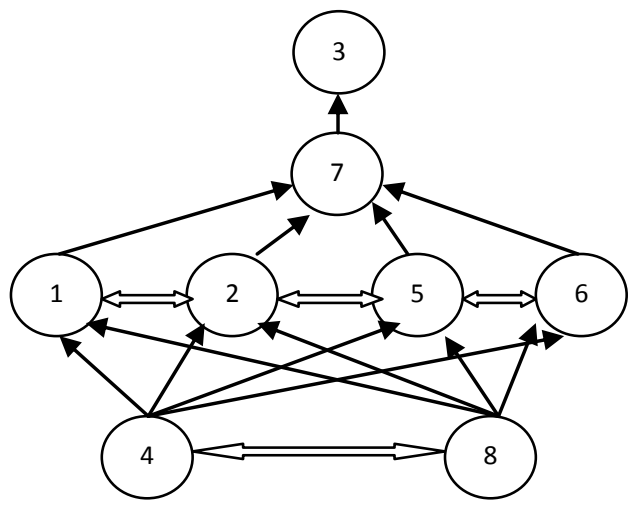

Gambar 12. Model dasar interaksi antar sub-unsur aktivitas pada ISM

\section{Pelaku}

Pada unsur pelaku, peubah perbankan dan lembaga keuangan lain (2), lembaga penjamin keuangan (4), penyuluh keuangan (5), dan LPK (Lembaga Pendidikan dan Keterampilan) (7) 
merupakan peubah yang berada pada top level dan paling memengaruhi unsur pelaku. Peubah yang berada pada top level ini memiliki driving power rendah dan ketergantungan antar peubah, yang artinya akan memiliki ketergantungan dengan peubah yang berada di middle level dan bottom level.

Peubah-peubah yang berada pada middle level ini akan memiliki pengaruh cukup besar terhadap peubah yang berhubungan dengan peubah terhubung. LSM (6) pada level ini dapat memaksimalkan kontribusinya, bila melakukan pembenahan kontribusi pada bottom level terlebih dahulu. Peubah yang berada pada bottom level ini memiliki sifat driver atau pengaruh kuat terhadap peubah yang berada di level atasnya, sehingga dapat meningkatkan kompetensi unggul petani.

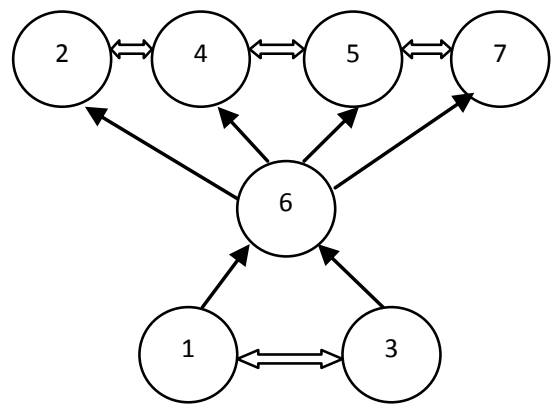

Gambar 13. Model dasar interaksi antar sub-unsur pelaku pada ISM

Memperbaiki kontribusi PEMDA (1) dan Perguruan Tinggi (3) dalam meningkatkan mutu petani secara tidak langsung akan memperbaiki kinerja konribusi dari unsur pelaku. Model dasar interaksi antar sub-unsur pelaku pada ISM dapat dilihat pada Gambar 13.

\section{Mengetahui dan Mengukur Kompetensi Unggul Petani dengan IPA}

IPA merupakan suatu metode dimana akan dilihat antara tingkat kepentingan dengan kinerja yang dilakukan di lapangan, sehingga dengan mudah melihat faktor mana yang harus diperbaiki kinerjanya, agar tercapainya tujuan. Gambar matriks IPA menunjukkan tiga belas faktor yang dapat mewakili pengukuran kompetensi petani unggul di Kabupaten Agam, Sumatera Barat dan Kabupaten Karo, Sumatera Utara.

\section{Analisis IPA pada Kabupaten Agam, Sumatera Barat}

Pada Gambar 14, daerah I menunjuk faktor yang memengaruhi kompetensi unggul petani, termasuk unsur sangat penting, tetapi tidak sesuai atau kinerjanya rendah di lapangan, sehingga menjadi prioritas utama yang harus dijalankan, agar para petani di Kabupaten Agam memiliki kompetensi unggul dalam bertani. Faktor yang terdapat pada daerah satu tersebut adalah Networking (jejaring kerja) yang luas merupakan kompetensi yang perlu dimiliki oleh petani agar cepat dalam berkembang (7) dan Teknologi dalam aktivitas penggunaan alat-alat pertanian merupakan faktor penting dalam berkembang (9).

Daerah II menunjukkan faktor yang memengaruhi kompetensi unggul petani dan kinerjanya sudah baik pula di lapangan, sehingga faktor-faktor yang terdapat didaerah ini harus dipertahankan kinerjanya di lapangan, yaitu Pelatihan oleh Pemerintah guna pengembangan sektor pertanian (2), Kompetensi keterampilan teknis pekerjaan dalam bertani harus dikuasai oleh seluruh petani guna terciptanya inovasi-inovasi (5), Pengalaman bertani yang baik menjadi faktor penting dalam memiliki kompetensi unggul (8), serta Operasi dan pemeliharaan pertanian yang baik, guna peningkatan produksi pertanian (13).

Daerah III menunjukkan faktor yang tidak terlalu nyata dalam memengaruhi kompetensi unggul petani dan kinerja di lapangannya rendah, sehingga faktor-faktor pada daerah ini merupakan prioritas rendah, yaitu Pengembangan kelembagaan di desa guna mempermudah petani berkembang (10), Pengembangan usaha pertanian komersialguna mempermudah petani berkembang (11), serta Kontribusi petani dan masyarakat guna mengembangkan investasi di desa (12).Daerah IV menunjukkan faktor yang tidak terlalu nyata dalam memengaruhi kompetensi unggul petani, tetapi kinerja di lapangannya baik, sehingga faktor-faktor pada daerah ini bersifat berlebihan, karena tidak dipentingkan, tetapi dilakukan dilapangan. Dalam hal ini Attitude merupakan kompetensi soft skill yang perlu dimiliki oleh para petani agar memiliki kompetensi yang unggul (6). Peubah yang terdapat antara daerah I dan daerah II adalah tersedianya sarana (benih, pupuk, pestisida, dll) pertanian yang memadai (3), dan tersedianya prasarana (alat-alat pertanian, teknologi pertanian, dll) pertanian yang memadai guna adanya motivasi untuk terus berkembang (4). Peubah-peubah ini sudah mendekati kearah kinerja yang baik, tetapi harus masih menjadi prioritas utama yang dijalankan, agar para petani di Kabupaten Agam memiliki kompetensi unggul dalam bertani. 


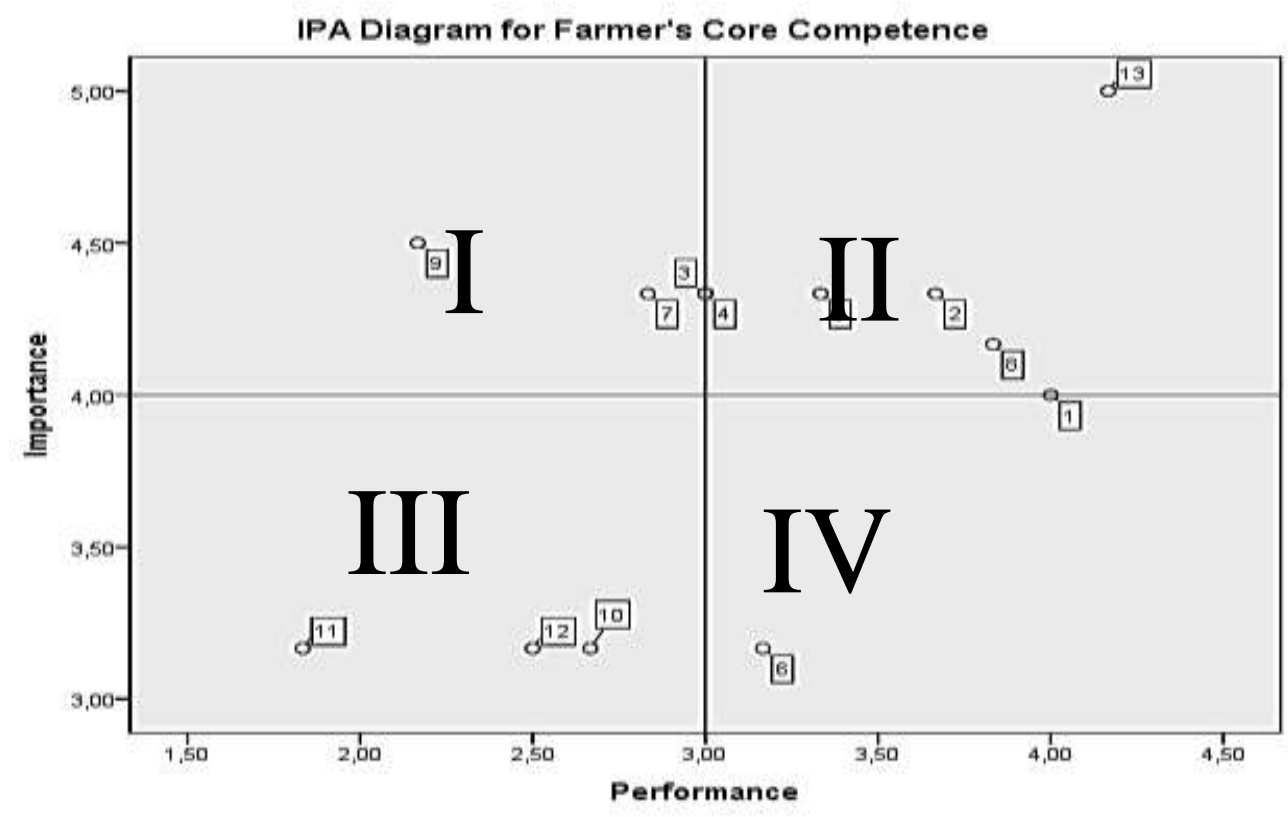

Gambar 14. Matriks analisis IPA untuk Kabupaten Agam, Sumatera Barat

Peubah yang terdapat antara daerah II dan daerah IV adalah pendidikan formal yang dimiliki petani merupakan faktor penting dalam kompetensi unggul petani (1), peubah ini menunjukan kinerjanya, baik di lapangan, tetapi harus menjadi prioritas utama agar menjadikan peubah ini menjadi suatu yang penting dibutuhkan dalam meraih kompetensi unggul petani di Kabupaten Agam.

\section{Analisis IPA pada Kabupaten Karo, Sumatera Utara}

Pada Gambar 15, daerah I menunjukkan faktor yang memengaruhi kompetensi unggul petani, termasuk unsur yang sangat penting, tetapi tidak sesuai atau kinerjanya rendah di lapangan, sehingga menjadi prioritas utama yang harus dijalankan, agar para petani di Kabupaten Karo memiliki kompetensi unggul dalam bertani.

Faktor yang terdapat pada daerah satu tersebut adalah tersedianya prasarana (alat-alat pertanian, teknologi pertanian, dan lain-lain) pertanian yang memadai guna adanya motivasi untuk terus berkembang (4) dan Teknologi dalam aktivitas penggunaan alat-alat pertanian sebagai faktor penting dalam berkembang (9).

Daerah II menunjukkan faktor yang memengaruhi kompetensi unggul petani dan kinerjanya sudah baik di lapangan, sehingga faktor-faktor yang terdapat di daerah ini harus dipertahankan kinerjanya di lapangan, yaitu Kompetensi keterampilan teknis pekerjaan dalam bertani yang harus dikuasai oleh seluruh petani guna terciptanya inovasi-inovasi (5), Networking (jejaring kerja) yang luas merupakan kompetensi yang perlu dimiliki oleh petani, agar cepat dalam berkembang (7), Pengalaman bertani yang baik menjadi faktor penting dalam memiliki kompetensi unggul (8), serta Operasi dan pemeliharaan pertanian yang baik guna peningkatan produksi pertanian (13).

Daerah III menunjukkan faktor yang tidak terlalu nyata dalam memengaruhi kompetensi unggul petani dan kinerja di lapangannya rendah, sehingga faktor-faktor pada daerah ini merupakan prioritas rendah, dimana Attitude merupakan kompetensi soft skill yang perlu dimiliki oleh para petani agar memiliki kompetensi unggul (6), Pengembangan kelembagaan di desa guna mempermudah petani berkembang (10), Pengembangan usaha pertanian komersial guna mempermudah petani berkembang (11).

Daerah IV menunjukkan faktor yang tidak terlalu nyata dalam memengaruhi kompetensi unggul petani, tetapi kinerja dilapangannya baik, sehingga faktor-faktor pada daerah ini bersifat berlebihan, karena tidak dipentingkan, tetapi dilakukan di lapangan, yaitu Kontribusi petani dan masyarakat guna mengembangkan investasi di desa (12).

Peubah yang terdapat antara daerah I dan daerah II adalah Pelatihan oleh Pemerintah guna pengembangan sektor pertanian (2), Tersedianya sarana (benih, pupuk, pestisida, dll) pertanian yang memadai (3). Peubah-peubah ini sudah mendekati ke arah kinerja yang baik, tetapi harus masih menjadi prioritas utama dijalankan, agar para petani di Kabupaten Agam memiliki kompetensi unggul dalam bertani. 


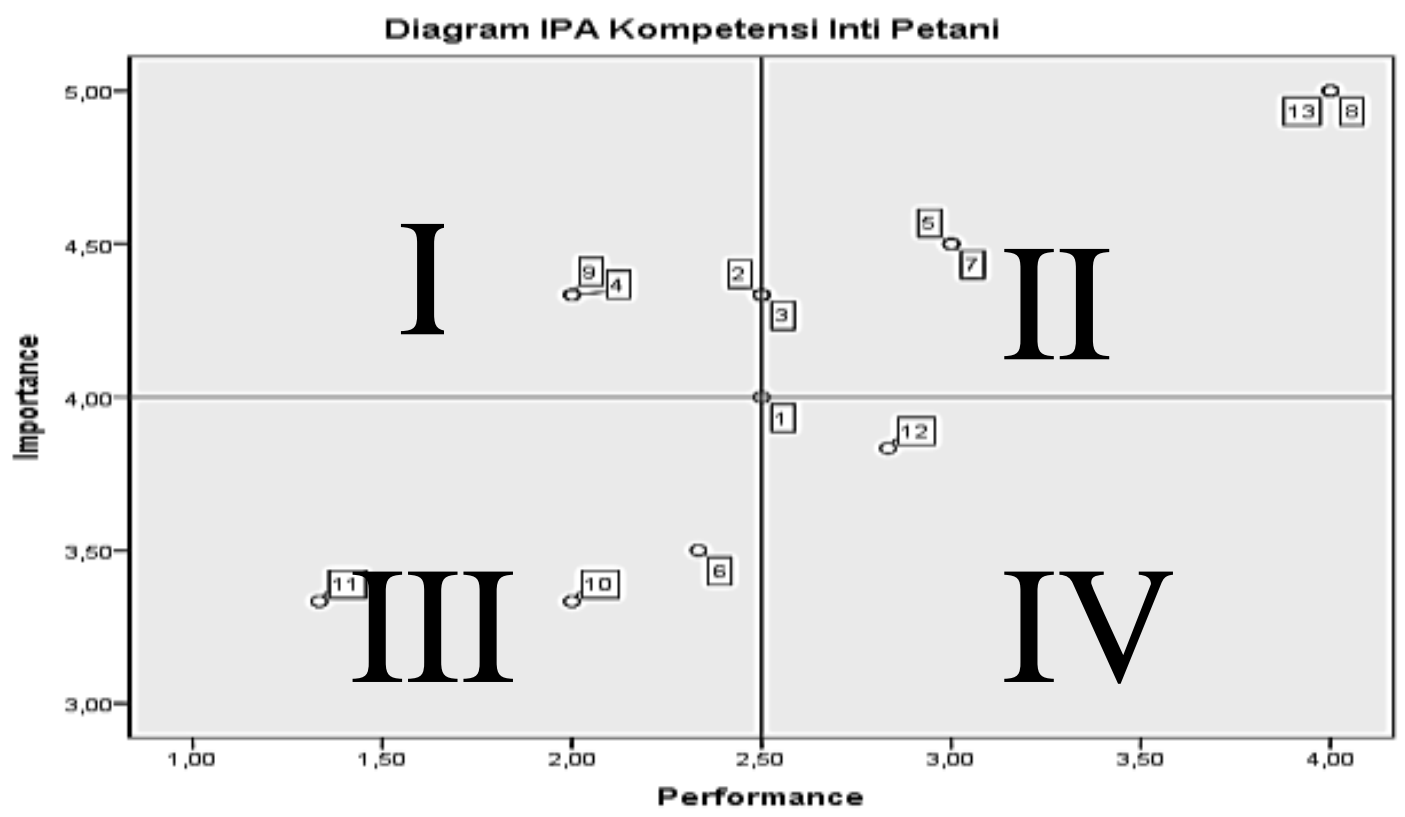

Gambar 15. Matriks analisis IPA untuk Kabupaten Karo, Sumatera Utara

Pendidikan formal yang dimiliki petani merupakan faktor penting dalam kompetensi unggul petani (1) sebagai peubah yang berada tepat ditengah-tengah diagram menunjukkan kepentingan maupun kinerjanya masih rataan di lapangan, tetapi harus menjadi prioritas utama, agar peubah ini menjadi suatu yang penting dibutuhkan dalam meraih kompetensi unggul petani di Kabupaten Agam.

\section{KESIMPULAN}

Kompetensi unggul petani sayuran di Kabupaten Karo dirasa masih belum maksimal, bila dilihat dari masih banyaknya petani yang belum memiliki motivasi terus berkembang, yaitu menjadi petani yang dapat menciptakan nilai tambah. Untuk kompetensi unggul petani sayuran di Kabupaten Agam sudah terlihat baik, dikarenakan adanya kerjasama antara petani dan PEMDA, tetapi masih ada sedikit kekurangan pada masalah pemanfaatan teknologi pertanian oleh petani.

Hasil dari model kompetensi unggul petani di wilayah Sumatera adalah terpenuhimya pemenuhan kebutuhan sarana pertaniandi Sumatera, serta adanya aktivitas PEMDA dalam meningkatkan sarana dan prasarana pertanian, dengan kendala utama yang dihadapi petani di Sumatera seperti penerapan teknologi yang belum optimal akan terminimalisir, sehingga petani akan mudah dalam menghasilkan sayuran mutu tinggi. Upaya dalam mewujudkan kompetensi unggul petani, dilakukan dengan melihatmasing-masing enam unsur ISM pada Kabupaten Karo dan Kabupaten Agam dalam menciptakan kompetensi unggul petani sayuran dataran tinggi di Sumatera.

\section{DAFTAR PUSTAKA}

[BPS] Badan Pusat Statistik. 2012. Nilai Produk Domestik Bruto Menurut Lapangan Usaha Tahun 2011-2013. [Internet]. [diunduh 2014 Feb 5]. Tersedia pada: http://www.bps.go.id/ about/nilai-produk-domestik-bruto-menurutlapangan-usaha.html

[BPS] Badan Pusat Statistik. 2012. Penyerapan Tenaga Kerja Menurut lapangan Usaha Tahun 2011-2013. [Internet]. [diunduh 2014 Feb 5]. Tersedia pada: http://www.bps.go.id/ about/penyerapan-tenaga-kerja-menurutlapangan-usaha.html

[BPS] Badan Pusat Statistik Provinsi Sumatera Barat. 2013. Produk Domestik Regional Bruto Sumatera Barat Tahun 2013. [Internet]. [diunduh 2014 Feb 5]. Tersedia pada: http://www.sumbar.bps.go.id/about/produkdomestik-regional-bruto-sumatera-barat2013.html

[UPT BP4K2P] Unit Pelaksana Teknis Balai Pelaksana Penyuluhan Pertanian, Perikanan, Kehutanan dan Ketahanan Pangan Kecamatan Baso, Kabupaten Agam. 2012. Program Penyuluhan Pertanian. Agam (ID). 
Hasibuan, S.P., Melayu, 1997, Manajemen Sumber Daya Manusia, Dasar dan Kunci Keberhasilan. Penerbit Gunung Agung, Jakarta.

Indrawanto, C. 2009. Kajian Pengem-bangan Industri Akar Wangi (Vetiveria zizanoides L.) menggunakan Interpretive Structural Modeling. Informatika Pertanian Volume 18 No. 1. Pusat Penelitian dan Pengembangan Perkebunan, Bogor.

Raeesi, R., D. Meisam., M. Sahar., and R. Ehsan. 2013. Understanding the Interactions among The Barriers to Entrepreneurship Using Interpretive Structural Modelling. International Journal of Business and Management, Vol. 8 No. 13. Iran.
Saaty, T.L. 1991. Pengambilan Keputusan. Bagi Para Pemimpin. Setiono L, penerjemah; Peniwati L, editor. PT Dharma Aksara Perkasa, Jakarta (ID). Terjemahan dari: Decision Making for Leaders. The Analytical Hierarchy Process for Decisions in Complex World.

Sumarni. 2008. Efektivitas Pelatihan di Pusat Pelatihan Pertanian Pedesaan Swadaya (P4S) Bulu Ballea dalam Meningkatkan Kompetensi Petani Sayuran Dataran Tinggi di Malino Kabupaten Gowa (Thesis). Program Pascasarjana Universitas Hasanuddin, Makassar. 